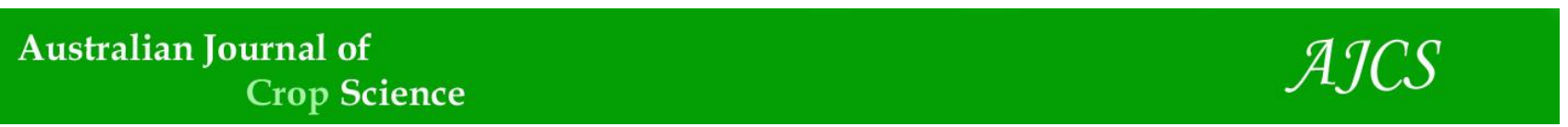

AJCS 14(05):761-765 (2020)

ISSN:1835-2707

doi: 10.21475/ajcs.20.14.05.p2124

\title{
Correlation analysis of the SPAD readings and yield of sweet potato (Ipomoea batatas L.) under different agrotechnical conditions
}

\author{
Péter Pepó \\ University of Debrecen, Faculty of Agricultural and Food Sciences and Environmental Management, Institute of Crop \\ Sciences, Hungary
}

Abstract

We studied the effect of planting method (flat and ridge planting) and row spacing (0.75-1.0 $\mathrm{m}$ ) on the yield and SPAD readings of sweet potato (Ásotthalmi 12 variety) in a small-plot field experiment in 2017 and 2018. The experiment was set up in lattice design with 4 replications. The SPAD readings of sweet potato were measured four (2017) and three (2018) times during vegetation period (by Konica Minolta 502). A high yield level was reached both in 2017 (23.23-50.69 t ha ${ }^{-1}$ marketable yield) and 2018 (33.26-47.34 t $\mathrm{ha}^{-1}$ ) due to the effects of the favourable soil (chernozem), the near-optimal agrotechnical background, irrigation and the warmerthan-average vegetation period. In both years, higher yields were obtained with flat planting and $0.75 \mathrm{~m}$ row spacing. The proportion of non-marketable tubers was between $9.97-15.57 \%$ in 2017 and $8.65-11.01 \%$ in 2018 . The SPAD $\max$ values were measured in July (39.61-50.31 in 2017) and in August (49.90-55.33 in 2018). Strong correlation observed among SPAD readings, the whole yield and the marketable yield in both years $(r=0.632 *, r=-0.664 *$ and $r=0.709 * *$, respectively). Also, a strong correlation was observed between the planting method and the obtained SPAD readings $(r=-0.847 *,-0.682 *$ in 2017 and $r=-0.634 *,-0.488$ in 2018, respectively), while there was no correlation between row spacing and SPAD readings $\left(r=-0.006^{\mathrm{NS}}-0.190^{\mathrm{NS}}\right)$. Crop year had a strong effect on SPAD readings $\left(r=0.639^{* *}-0.871^{* *}\right)$.

Keywords: correlation, LAI, planting method, row space, SPAD, sweet potato.

Abbreviations: LAI_Leaf Area Index, LSD_Least Significant Difference, SPAD_Soil Plant Analysis Development.

Introduction

Sweet potato (Ipomoea batatas L.) is of tropical or subtropical origin. In recent decades, it has been producing in an increasing number of European countries with temperate climate (e.g., Spain, Italy). Sweet potato is the 7th most important food crop in the world and is the 4th most significant crop in tropical countries (Julianti et al. 2017). Its tuber yield has high carbohydrate content, but it also contains significant amounts of vitamins $\left(C, B_{1}, B_{2}, B_{6}, E\right)$ and minerals (Woolfe 1992, Bovell-Benjamin 2007, Guo et al. 2014). Sweet potato has high potential productivity (Hall and Harmon 1989, Varma et al. 1994, Coertze and Ven den Berg 1995). However, average yields are low in the world's large sweet potato producing countries (de la Peña 1996). Due to its excellent adaptability (White and Zasoski 1999, Yan et al. 2006, Zuo and Zhang 2011), sweet potato is grown under a wide range of ecological and agrotechnical conditions.

In Hungary, sweet potato production began about 20 years ago. However, its production area increased to $600-800$ ha only in the last few years. Sweet potato is produced mainly by means of ridge planting, but flat planting is also an option (Clark 2013). Different row spacings (0.81-1.22 $\mathrm{m}$ ) and planting distances $(0.25-0.40 \mathrm{~m})$ can be used (Coolong et al. 2012, NCSPC 2015, Szarvas et al. 2017, Pepó 2018). The agronomic and physiological properties of sweet potato were studied under tropical conditions (Chen et al. 2006, Surayia 2006, Solomon et al. 2015). Grafting experiments have suggested that the productivity of sweet potato is due to the sink strength of tuberous root, i.e. its capacity to deposit and store the products of photosynthesis (Hozyo et al. 1971, Harn 1977). Su et al. (2009) showed that there was a strong, positive correlation between the chlorophyll content of sweet potato and SPAD readings.

We could find several scientific data of the SPAD readings and the yield of sweet potato in subtropical and tropical climatic conditions. However, there are very limited references with experimental results under temperate climatic zone. The main aim of this study was to get preliminary scientific results of photosynthetic capacity (SPAD) and the yield of sweet potato in continental zone, where the sweet potato is a brand-new crop on arable land.

Results and Discussion

Effect of crop year, management factors on the SPAD
readings of sweet potato

SPAD readings of sweet potato were obtained four times in 2017 and three times in 2018 (Table 1). The SPAD values increased until 21st July in 2017 and 7th August in 2018, followed by a decrease. SPAD $\max$ values varied between 39.81-50.31 in 2017 and 49.90-55.33 in 2018, respectively. In both years, the SPAD readings in the case flat planting were significantly higher than the values obtained in ridge planting. In 2017, the SPAD values obtained at $0.75 \mathrm{~m}$ row 
Table 1. Effect of planting method and row spacing on the SPAD readings of sweet potato (Debrecen, 2017-2018).

\begin{tabular}{|c|c|c|c|c|c|c|c|}
\hline \multirow{3}{*}{$\begin{array}{l}\text { Planting method } \\
\text { Row distance }\end{array}$} & \multicolumn{7}{|c|}{ SPAD readings } \\
\hline & \multicolumn{4}{|c|}{2017} & \multicolumn{3}{|c|}{2018} \\
\hline & 10 July & 21 July & 17 August & 07 October & 09 July & 07 August & 18 September \\
\hline \multicolumn{8}{|l|}{ Flat } \\
\hline $1.0 \mathrm{~m}$ between rows & $44.05 b$ & $50.31 c$ & $49.72 a$ & $38.89 a$ & $49.70 a$ & $54.30 \mathrm{~b}$ & $48.27 a$ \\
\hline $0.75 \mathrm{~m}$ between rows & $48.07 c$ & $49.30 b c$ & $49.08 a$ & $39.44 a$ & $53.13 b$ & $55.33 b$ & $50.50 \mathrm{~b}$ \\
\hline \multicolumn{8}{|l|}{ Ridge } \\
\hline $1.0 \mathrm{~m}$ between rows & $40.14 a$ & $39.61 a$ & $48.93 a$ & $42.47 b$ & $47.70 a$ & $53.67 b$ & $54.00 c$ \\
\hline $0.75 \mathrm{~m}$ between rows & $39.10 a$ & $45.19 b$ & 49.49a & $43.31 b$ & $48.67 a$ & $49.90 \mathrm{a}$ & $49.93 a$ \\
\hline $\mathrm{LSD}_{5 \%}$ & 2.16 & 3.07 & 1.02 & 1.15 & 3.71 & 3.05 & 2.10 \\
\hline
\end{tabular}

$a, b, c$ Letters are significantly different at $\mathrm{P} \leq 0.05$ level

Table 2. Effect of planting method and row spacing on the yields of sweet potato (Debrecen, 2017-2018).

\begin{tabular}{|c|c|c|c|c|c|c|}
\hline \multirow{2}{*}{$\begin{array}{l}\text { Planting methods } \\
\text { Row distance }\end{array}$} & \multicolumn{3}{|c|}{2017} & \multicolumn{3}{|c|}{2018} \\
\hline & $\begin{array}{c}\text { Total (grass) } \\
\text { yield } \\
\left(\mathrm{kg} \mathrm{ha}^{-1}\right)\end{array}$ & $\begin{array}{c}\text { Marketable } \\
\text { (net) yield } \\
\left(\mathrm{kg} \mathrm{ha}^{-1}\right)\end{array}$ & $\begin{array}{l}\text { Ratio of non- } \\
\text { marketable } \\
\text { yield }(\%)\end{array}$ & $\begin{array}{c}\text { Total (grass) } \\
\text { yield } \\
\left(\mathrm{kg} \mathrm{ha}^{-1}\right)\end{array}$ & $\begin{array}{c}\text { Marketable } \\
\text { (net) yield } \\
\left(\mathrm{kg} \mathrm{ha}^{-1}\right)\end{array}$ & $\begin{array}{l}\text { Ratio of non- } \\
\text { marketable } \\
\text { yield }(\%)\end{array}$ \\
\hline \multicolumn{7}{|l|}{ Flat } \\
\hline $1.0 \mathrm{~m}$ between rows & 35 497ab & 32 200ab & $9.97 a$ & $38391 a$ & $34883 a$ & $9.17 a b$ \\
\hline $0.75 \mathrm{~m}$ between rows & $56816 c$ & $50689 c$ & 10.90ab & $51830 c$ & $47339 b$ & $8.65 a$ \\
\hline \multicolumn{7}{|l|}{ Ridge } \\
\hline $1.0 \mathrm{~m}$ between rows & $27467 a$ & $23233 a$ & $15.57 c$ & $36771 a$ & 33 260a & $9.60 a b$ \\
\hline $0.75 \mathrm{~m}$ between rows & $45352 b$ & $39356 b$ & $13.03 b$ & $41580 b$ & 37 014ab & $11.01 b$ \\
\hline $\mathrm{LSD}_{5 \%}$ & 10986 & 9950 & 2.07 & 9505 & 8700 & 1.90 \\
\hline
\end{tabular}

$a, b, c$ Letters are significantly different at $P \leq 0.05$ level.

Table 3. Pearson correlation analysis among the planting method, row spacing, yield and SPAD of sweet potato (Debrecen, 2017).

\begin{tabular}{|c|c|c|c|c|c|}
\hline & \multirow{2}{*}{$\begin{array}{c}\text { Marketable yield } \\
\left(\mathrm{kg} \mathrm{ha}^{-1}\right)\end{array}$} & \multicolumn{4}{|c|}{ SPAD readings } \\
\hline & & 10 July & 21 July & 17 August & 07 October \\
\hline $\begin{array}{l}\text { Planting method } \\
\text { (ridge / flat) }\end{array}$ & $-0.460^{*}$ & $-0.789 * *$ & $-0.847^{* *}$ & $-0.062^{\text {NS }}$ & $0.682^{*}$ \\
\hline $\begin{array}{l}\text { Row spacing } \\
(1.0,0.75 \mathrm{~m})\end{array}$ & $0.784^{*}$ & $0.183^{\mathrm{NS}}$ & $0.261^{\mathrm{NS}}$ & $-0.015^{\mathrm{NS}}$ & $0.130^{\mathrm{NS}}$ \\
\hline $\begin{array}{l}\text { Total yield } \\
\left(\mathrm{kg} \mathrm{ha}^{-1}\right)\end{array}$ & $0.991^{* *}$ & $0.609 *$ & $0.613^{*}$ & $-0.078^{\mathrm{NS}}$ & $0.135^{\mathrm{NS}}$ \\
\hline $\begin{array}{l}\text { Marketable yield } \\
\left(\mathrm{kg} \mathrm{ha}^{-1}\right)\end{array}$ & & $0.632^{*}$ & $0.664^{*}$ & $-0.089^{\mathrm{NS}}$ & $0.131^{\mathrm{NS}}$ \\
\hline $\begin{array}{l}\text { Ratio of non- } \\
\text { marketable yield }(\%)\end{array}$ & & $-0.343^{\mathrm{NS}}$ & $-0.688^{*}$ & $0.169^{N S}$ & $0.061^{\mathrm{NS}}$ \\
\hline
\end{tabular}

${ }^{* *}$ Correlation at $\mathrm{LSD}_{0.01}$ level, ${ }^{*}$ Correlation at $\mathrm{LSD}_{0.05}$ level, $\mathrm{NS}=$ non-significant.

Table 4. Pearson correlation analysis among the planting method, row spacing, yield and SPAD of sweet potato (Debrecen, 2018).

\begin{tabular}{|c|c|c|c|c|}
\hline & \multirow{2}{*}{$\begin{array}{l}\text { Marketable yield } \\
\left(\mathrm{kg} \mathrm{ha}^{-1}\right)\end{array}$} & \multicolumn{3}{|c|}{ SPAD readings } \\
\hline & & 09 July & 07 August & 18 September \\
\hline $\begin{array}{l}\text { Planting method } \\
\text { (ridge / flat) }\end{array}$ & $-0.497^{*}$ & $-0.634^{*}$ & $-0.499^{\mathrm{NS}}$ & $0.488^{\mathrm{NS}}$ \\
\hline $\begin{array}{l}\text { Row spacing } \\
(1.0,0.75 \mathrm{~m})\end{array}$ & $0.675^{*}$ & $0.431^{\mathrm{NS}}$ & $-0.225^{\mathrm{NS}}$ & $-0.170^{\mathrm{NS}}$ \\
\hline $\begin{array}{l}\text { Total yield } \\
\left(\mathrm{kg} \mathrm{ha}^{-1}\right)\end{array}$ & $0.998 * *$ & $0.709 * *$ & $0.180^{\mathrm{NS}}$ & $-0.232^{\mathrm{NS}}$ \\
\hline $\begin{array}{l}\text { Marketable yield } \\
\left(\mathrm{kg} \mathrm{ha}^{-1}\right)\end{array}$ & & $0.709 * *$ & $0.232^{\mathrm{NS}}$ & $-0.213^{\mathrm{NS}}$ \\
\hline $\begin{array}{l}\text { Ratio of non-marketable yield } \\
\text { (\%) }\end{array}$ & & $-0.279^{\mathrm{NS}}$ & $0.749 * *$ & $-0.129^{\mathrm{NS}}$ \\
\hline
\end{tabular}


Table 5. Pearson correlation analysis among the planting method, row spacing, yield and SPAD of sweet potato (Debrecen, 20172018).

\begin{tabular}{|c|c|c|c|c|}
\hline & \multirow{2}{*}{$\begin{array}{l}\text { Marketable yield } \\
\left(\mathrm{kg} \mathrm{ha}^{-1}\right)\end{array}$} & \multicolumn{3}{|c|}{ SPAD readings } \\
\hline & & Early July & Late July-Early August & Mid-August \\
\hline Crop year & $0.098^{\mathrm{NS}}$ & $0.715^{* *}$ & $0.639 * *$ & $0.871^{* *}$ \\
\hline $\begin{array}{l}\text { Planting method } \\
\text { (ridge / flat) }\end{array}$ & $-0.452 *$ & $-0.497^{*}$ & $-0.258^{\mathrm{NS}}$ & $0.287^{\mathrm{NS}}$ \\
\hline $\begin{array}{l}\text { Row spacing } \\
(1.0,0.75 \mathrm{~m})\end{array}$ & $0.712 * *$ & $0.190^{\mathrm{NS}}$ & $-0.113^{\mathrm{NS}}$ & $-0.006^{\mathrm{NS}}$ \\
\hline $\begin{array}{l}\text { Total yield } \\
\left(\mathrm{kg} \mathrm{ha}^{-1}\right)\end{array}$ & $0.991 * *$ & $0.473^{*}$ & $0.062^{\mathrm{NS}}$ & $-0.051^{\text {NS }}$ \\
\hline $\begin{array}{l}\text { Marketable yield } \\
\left(\mathrm{kg} \mathrm{ha}^{-1}\right)\end{array}$ & & $0.522 * *$ & $0.112^{\mathrm{NS}}$ & $0.004^{\mathrm{NS}}$ \\
\hline $\begin{array}{l}\text { Ratio of non-marketable yield } \\
\text { (\%) }\end{array}$ & & $-0.549 * *$ & $-0.408^{*}$ & $-0.439 *$ \\
\hline
\end{tabular}

**Correlation at $\mathrm{LSD}_{0.01}$ level, *Correlation at $\mathrm{LSD}_{0.05}$ level, $\mathrm{NS}=$ non-significant.

Table 6. The most important traits of experimental soil (Debrecen, plowing layer).

\begin{tabular}{lccccccc}
\hline \multirow{2}{*}{ Humus (\%) } & \multirow{2}{*}{ Soil plasticity $\mathrm{K}_{\mathrm{A}}$} & \multicolumn{2}{c}{$\mathrm{pH}$} & \multirow{2}{*}{$\mathrm{CaCO}_{3}(\%)$} & \multicolumn{2}{c}{$\mathrm{AL}$-soluble } \\
\cline { 3 - 4 } & & $\mathrm{H}_{2} \mathrm{O}$ & $\mathrm{KCl}$ & & $\mathrm{P}_{2} \mathrm{O}_{5}\left(\mathrm{mg} \mathrm{kg}^{-1}\right)$ & $\mathrm{K}_{2} \mathrm{O}\left(\mathrm{mg} \mathrm{kg}^{-1}\right)$ \\
\hline 2.57 & 42.0 & 7.0 & 6.5 & - & 100.0 & 165.0 \\
\hline
\end{tabular}

Table 7. The most important meteorological data of experimental site (Debrecen).

\begin{tabular}{|c|c|c|c|c|c|c|c|}
\hline & $\begin{array}{l}\text { Rainfall autumn and } \\
\text { winter }(\mathrm{mm}) \\
\text { (Sept-Febr) }\end{array}$ & $\begin{array}{c}\text { Rainfall in } \\
\text { spring (mm) } \\
\text { (March-May) }\end{array}$ & June & July & August & September & $\begin{array}{c}\text { Sum }(\mathrm{mm}) \\
\text { Mean }\left({ }^{\circ} \mathrm{C}\right) \\
\text { in vegetation period }\end{array}$ \\
\hline \multicolumn{8}{|l|}{ Rainfall } \\
\hline$\overline{2017 \text { year }}$ & 210.2 & 106.8 & 62.3 & 71.6 & 47.5 & 91.7 & 273.1 \\
\hline 2018 year & 369.0 & 165.1 & 66.8 & 41.9 & 97.5 & 20.6 & 226.8 \\
\hline 30 years mean & 186.7 & 147.0 & 66.5 & 66.1 & 49.0 & 47.5 & 229.1 \\
\hline \multicolumn{8}{|l|}{ Temperature } \\
\hline 2017 year & - & - & 20.9 & 21.0 & 22.1 & 15.5 & 19.9 \\
\hline 2018 year & & & 20.1 & 21.7 & 23.2 & 17.1 & 20.5 \\
\hline 30 years mean & & & 19.4 & 21.3 & 20.7 & 15.8 & 19.3 \\
\hline
\end{tabular}

spacing were higher than those of the $1.0 \mathrm{~m}$ row spacing regarding both planting methods. In 2018, the SPAD readings obtained in flat planting were higher at $0.75 \mathrm{~m}$ row spacing, while the readings of ridge planting were higher in the case of the $1.0 \mathrm{~m}$ row spacing. Higher SPAD readings enabled higher photosynthetic intensity (Su et al., 2009). The organic matter production resulted in higher tuber yield (Hozyo et al. 1971, Harn 1977).

\section{Effect of crop year, management factors on the yields of sweet potato}

The effects of the favourable soil (chernozem), near-optimal agrotechnology, irrigation and the higher-than-average temperature of both growing years resulted in a favourable yield (Table 2). The total yield was 27.47-56.82 $\mathrm{t} \mathrm{ha}^{-1}$ in 2017 , $36.77-51.83 \mathrm{t} \mathrm{ha}^{-1}$ in 2018 . The marketable yield was $23.23-$ 50.69 $\mathrm{t} \mathrm{ha}^{-1}$ and 33.26-47.34 $\mathrm{t} \mathrm{ha}^{-1}$, depending on the planting method and row spacing. In both years, higher yields were obtained in flat planting at $0.75 \mathrm{~m}$ row spacing. With regard to marketable yield, the yield difference between the two row spacings was $11.33 \mathrm{t} \mathrm{ha}^{-1}$ in flat planting and $16.12 \mathrm{t} \mathrm{ha}^{-1}$ in ridge planting in 2017, as well as $12.46 \mathrm{t} \mathrm{ha}^{-1}$ and $3.75 \mathrm{t} \mathrm{ha}^{-1}$ in 2018, respectively, i.e. significant yield differences were obtained. At the same row spacing of flat planting, yield was increased by $8.97 \mathrm{t} \mathrm{ha}^{-1}$ at $1.0 \mathrm{~m}$ row spacing and $11.33 \mathrm{t} \mathrm{ha}^{-1}$ at $0.75 \mathrm{~m}$ row in 2017, compared to ridge planting. In 2018, the observed differences were $1.62 \mathrm{t} \mathrm{ha}^{-1}$ and $10.33 \mathrm{t} \mathrm{ha}^{-1}$ in favour of flat planting. The proportion of non-marketable tubers was higher in 2017 (9.97-15.57\%) than in 2018 (8.65-11.01\%), which can be explained by the continuous irrigation in 2018 (June-July-August) and the more favourable temperatures. The sweet potato experiments carried out on chernozem soil in 2017 and 2018 proved that this tropical crop can adapt to the wide-range of ecological conditions if the proper agrotechnical background is provided, similar to the reports of Yan et al. (2006), Lebot (2009), as well as Zuo and Zhang (2011). In conformity with other experiments (Coertze and Van den Berg 1995), high yields were harvested in our sweet potato experiment. The non-marketable tuber yield varied between 23.2-50.7 $\mathrm{t} \mathrm{ha}^{-1}$ in 2017 and between 33.3-47.3 $\mathrm{t}$ $\mathrm{ha}^{-1}$ in 2018, depending on the planting method and row spacing. In contrast to Lebot (2009), Coolong et al. (2012) and Clark (2015), we obtained higher whole yield and marketable yield in the case of flat planting in both years (32.2-50.7 $\mathrm{t} \mathrm{ha}^{-1}$ in 2017 and 34.9-47.3 $\mathrm{t} \mathrm{ha}^{-1}$ in 2018) compared to ridge planting (23.2-39.4 $\mathrm{tha}^{-1}$ and 33.3-37.0 $\mathrm{t}$ $\mathrm{ha}^{-1}$, respectively).

\section{Correlations among SPAD and yields}

The correlations between different factors were evaluated for each year using Pearson's correlation (Tables 3 and 4), averaged over the examined years (Table 5). The marketable yield of sweet potato is mainly determined by row spacing in both years and also averaged over the examined years $(r=$ $0.784^{*}$ in $2017, r=0.675^{*}$ in 2018 and $r=0.712^{* *}$ averaged 
over the different years). However, the planting method also had a significant effect $\left(r=-0.460^{* *}, r=-0.497^{*}, r=-\right.$ $\left.0.452^{*}\right)$. Due to the favourable condition for both crop years, no crop year effect was observed in the examined years $(r=$ $0.098^{\mathrm{NS}}$ ). In 2017, a strong correlation was observed between SPAD readings in July and the two planting methods $\left(r=-0.789 * *-0.847^{* *}\right)$, total yield $(r=0.609 *$ $\left.0.613^{*}\right)$ and marketable yield ( $\left.r=0.632^{*}-0.664^{*}\right)$. In 2018, only the SPAD readings in July showed close correlation between these data $\left(r=-0.634^{*}, r=0.709 * *, r=0.709 * *\right)$. Based on the experimental data of the two years, the highest correlation was observed between crop year and SPAD readings $\left(r=0.715^{* *}, r=0.639^{* *}, r=0.871^{* *}\right.$ on each occasion when SPAD readings were obtained). The SPAD readings in July showed a medium correlation with the planting method $\left(r=-0.497^{*}\right)$, the whole yield $\left(r=0.473^{*}\right)$, as well as the marketable yield $\left(r=0.522^{* *}\right)$ and the ratio of non-marketable yield $\left(r=-0.549^{* *}\right)$, while there was no correlation for row spacing $(r=0.190)$.

According to our results, high correlation was observed between the SPAD values in July, the whole yield and the marketable yield in $2017\left(r=0.609 *, r=0.632^{*}\right)$ and $2018(r$ $\left.=0.709^{* *}, r=0.709^{* *}\right)$. In 2017, high correlation was observed between the planting method and the SPAD readings $\left(r=-0.789 * *, r=-0.847^{* *}, r=0.682 * *\right.$, except for the SPAD readings in August). In 2018, medium correlation was found only between the SPAD readings in July and the planting method $\left(r=-0.634^{*}\right)$. Row spacing had no effect on SPAD values. Averaged over the two examined years, the crop year had a strong effect on SPAD readings $\left(r=0.715^{* *}\right.$, $\left.r=0.639^{* *}, r=0.871^{* *}\right)$. Based on our experiment findings and further measurements yet to be performed, there may be an opportunity to predict the expected yield of sweet potato based on the relatively early SPAD readings (to be obtained in July).

\section{Materials and methods}

\section{Plant material and experimental site}

The sweet potato variety "Ásotthalmi 12", adapted to Hungarian weather conditions, was used in the experiments. The skin of tuber is red and its pulp is orange, tasty and sweet. The cuttings were planted on $31^{\text {st }}$ May / $1^{\text {st }}$ June in 2017 and 2018.

The small-plot field experiments were set up in the Student's Garden of the Institute of Crop Sciences of the University of Debrecen with four replications in 2017 and 2018 (latitude $47^{\circ} 54^{\prime} 94^{\prime \prime}$ North, longitude $21^{\circ} 60^{\prime} 88^{\prime \prime}$ East).

\section{Soil traits and meteorological data of crop years}

The analytical results of the experimental soil (Table 6) showed that the calcareous chernozem soil is mid-heavy and belongs to the loam soil physical group. The humus content (2.57\%), AL-soluble $\mathrm{P}_{2} \mathrm{O}_{5}$ content $\left(100 \mathrm{mg} \mathrm{kg}^{-1}\right)$ and $\mathrm{K}_{2} \mathrm{O}$ content $\left(165 \mathrm{mg} \mathrm{kg}^{-1}\right)$ of the soil are average.

The meteorological data of two crop years (Table 7) show that the rainfall in the autumn and winter period (September-February) and in spring months (March-May) was less $(-21.2 \mathrm{~mm}$ and $-40.2 \mathrm{~mm}$ ) in 2017 compared to 30 year average $(231.4 \mathrm{~mm}$ and $147.0 \mathrm{~mm})$. In the same periods of 2018 , rainfall was plentiful ( $+137.6 \mathrm{~mm}$ and $+18.1 \mathrm{~mm}$ ) and made more dispensable water available in the chernozem soil. The amount and distribution of rainfall in the 2017 vegetation period $(273.1 \mathrm{~mm})$ were more favourable than the period between June-September in $2018(226.8 \mathrm{~mm})$. Even so, we had to irrigate in both 2017 and $2018(164 \mathrm{~mm}$ and $152 \mathrm{~mm}$ irrigation water, respectively). The temperatures in the vegetation periods of 2017 and 2018 were higher than the 30-year mean $\left(19.3^{\circ} \mathrm{C}\right)$ which had a positive effect on the leaf development and tuber formation of sweet potato originated from the tropical gene pool.

\section{Agrotechnology in trials}

The previous crop of the experiment was winter wheat in both years. Following the harvest of the forecrop, the usual operations were used on the soil (stubble cleaning and rolling, stubble maintenance with discing, 0.3-0.34 m deep autumn ploughing) and the properly loose structure and weed-free conditions of the soil were maintained with a cultivator in the spring. No nutrient replenishment was performed in the autumn. In the spring before planting, the following active ingredients of fertilizers were applied: $\mathrm{N}=$ $106 \mathrm{~kg} \mathrm{ha}^{-1} / 106 \mathrm{~kg} \mathrm{ha}^{-1}, \mathrm{P}_{2} \mathrm{O}_{5}=76 \mathrm{~kg} \mathrm{ha}^{-1} / 60 \mathrm{~kg} \mathrm{ha}^{-1}, \mathrm{~K}_{2} \mathrm{O}=$ $76 \mathrm{~kg} \mathrm{ha}^{-1} / 60 \mathrm{~kg} \mathrm{ha}^{-1}$ in 2017 / 2018. No chemical weed control was applied on the experimental site. Manual weed control was performed on four / four occasions in June and July (2017 / 2018). The experiment was harvested by hand on $10^{\text {th }}$ October $/ 1^{\text {st }}$ October in 2017 and 2018. During manual harvesting, the total tuber yield of plots and marketable and non-marketable tuber yield (tubers below $200 \mathrm{~g}$, damaged by insects and diseased tubers) were measured.

In both years, we used irrigation (by sprinkling method) on the experimental site. Due to weather conditions between $31^{\text {st }}$ May and $10^{\text {th }}$ July 2017, a total $164 \mathrm{~mm}$ of irrigation water was used. For the period between $1^{\text {st }}$ June and $14^{\text {th }}$ August 2018, a total $152 \mathrm{~mm}$ of irrigation water was used.

\section{Experimental design}

In the experiments, flat planting and ridge planting were used with $1.0 \mathrm{~m}$ and $0.75 \mathrm{~m}$ row spacing in both production methods. The planting distance of cuttings was $0.3 \mathrm{~m}$. Plot size was $4 \mathrm{~m}^{2}$, in 4 replications with lattice design.

\section{Trait measured}

The relative chlorophyll content (SPAD readings) of sweet potato leaves was measured on four (2017) and three (2018) occasions during the vegetation period. A Konica Minolta 502 meter was used to obtain SPAD readings. During each measurement session, 30 readings were obtained per plot in all four replications.

\section{Statistical analysis}

Statistical evaluation of the experimental data was performed using Microsoft Excel 2013 and SPSS for Windows 13.0. For the evaluation of the results, analysis of variance and Pearson's correlation analysis were used. The data were submitted to analysis of variance and to the $F$ test $(P \leq 0.05$, $P \leq 0.01$ ), and if significant, the averages of the factors were compared by the Tukey test at the probability level of $5 \%$ and $1 \%$. 


\section{Conclusion}

Sweet potato originating from a tropical genetic centre has special water and heat demands, but its adaptability to different soil and climate conditions is high. Under temperate climate (Hungary) and on chernozem soil, the marketable yields of sweet potato varied between 23.23$50.69 \mathrm{t} \mathrm{ha}^{-1}$ (2017 year) and 33.26-47.34 t ha- (2018 year). The flat planting and $0.75 \mathrm{~m}$ row spacing gave higher yields compared with ridge plating and $1.0 \mathrm{~m}$ row spacing. The ratio of non-marketable tubers was less in flat planting with $0.75 \mathrm{~m}$ row spacing. Because of the high correlation between the yield of sweet potato and SPAD values, there may be an opportunity to predict the expected yield based on early SPAD values.

\section{Acknowledgement}

The work/publication is supported by the EFOP-3.6.3.VEKOP-16-2017-00008 project. The project is co-financed by the European Union and the European Social Fund.

\section{References}

Bovell-Benjamin AC (2007) Sweet potato: A review of its past, present, and future role in human nutrition. Adv Food Nutr Res. 52:1-59.

Chen Z, Schols HA, Voragen AGJ (2006) Physicochemical Properties of Starches Obtained from Three Varieties of Chinese Sweet Potatoes. J Food Sci. 68:431-437.

Clark C (2013) Cultivation and storage. In: Clark CA, Ferrin DM, Smith TP, Holmes GJ (eds): Compendium of sweet potato disease, pests, and disorders. Second edition. APS Press, St. Paul, Minnesota. 4-7.

Coertze AF, Van den Berg AA (1995) Sweet Potato Cultivars. Agricultural Research Council Vegetable and Ornamental Plants (ARC-VOPI), South Africa. 18.

Coolong T, Seebold K, Bessin R, Woods T, Fannin S (2012) Sweetpotato production for Kentucky. ID-195. University of Kentucky Cooperative Extension Service, Lexington. KY 40506.

de la Peña RS (1996) Root crops in the Pacific region: their dietary, cultural and economic significance. In: Craswell ET, Asher CJ, O'Sullivan JN (eds), Mineral Nutrient Disorders of Root Crops in the South Pacific. Australian Centre for International Agricultural Research, Canberra. 19-27.

Guo J, Liu L, Lian X, Li L, Wu H (2014) The properties of different cultivars of Jinhai sweet potato starches in China. Int J Biol Macromol. 67(june):1-6.
Hall MR, Harmon SA (1989) Coastal red sweet potato. Hort Sci. 24:176-177.

Harn SK (1977) A quantitative approach to source potentials and sink capacities among reciprocal grafts of sweet potato varieties. Crop Sci. 17:559-562.

Hozyo Y, Murata T, Yoshida T (1971) The development of tuberous roots in grafting sweet potato plants, Ipomoea batatas Lam. Bull Nat Inst Agr Sci. 22:165-191.

Julianti E, Rusmarilin H, Ridwansyah-Yusraini E (2017) Functional and rheological properties of composite flour from sweet potato, maize, soybean and xanthan gum. J Saudi Soc Agricult Sci. 16(2):171-177.

Lebot V (2009) Tropical root and tuber crops: Cassava, sweet potato, yams and aroids. Crop Production Science in Horticulture. (17). CABI, Wallingford, UK. 413pp.

North Carolina Sweet Potato Commission (2015) Growing sweet potatoes in North Carolina: planting. (Online). https://ncsweetpotatoes.com/sweet-potatoindustry/growing-sweet-potatoes-in-northcarolina/planting/ (accessed 1 May 2015)

Pepó P (2018) The effect of different planting methods on the yield and SPAD readings of sweet potato (Ipomoea batatas L.). Columella. 5(1):7-12.

Solomon A, Wassu M, Beneberu S (2015) Agronomic and physicochemical evaluation of sweet potato [Ipomoea batatas (L.) Lam.] collections in Ethiopia. Adv Sci Crop Sci Technol. 3:172.

Su YS, Guo HC, Yang XL (2009) Study on correlations between SPAD readings and chlorophyll content in leaves of sweet potato, dioscorea and konjaku. Southwest China Journal of Agricultural Sciences. 22(1):64-66.

Surayia Z, Sarwar M, Jonathan A, Khan MN, Butt MS (2006) Variation in Physio-Chemical Characteristics of Some Cultivars of Sweet Potato. Pak J Bot. 38:283-291.

Szarvas A, Váraljai T, Monostori T (2017) Sweet potato production on alluvial soil with high clay content. Annals Agr Silv Vet. 6(1):68-75.

Varma VS, Singh HP, Singh NK, Singh JRP, Mishra S, Sahu MP, Kumari K, Ray R (1994) Rejendra shakarkand 35 and Rejendra shakarkand 43: Two high yielding selections of sweet potato. J Root Crops. 20:15-19.

White JG, Zasoski RJ (1999) Mapping soil micronutrients. Field Crop Res. 60:11-26.

Woolfe J (1992) Sweetpotato: An Untapped Food Resource. Cambridge University Press. 1-13., 366-372.

Yan X, Wu P, Ling H, Xu G, Xu F, Zhang Q (2006) Plant nutriomics in China: an overview. Ann Bot. 98: 473-482.

Zuo Y, Zhang F (2011) Soil and crop management strategies to prevent iron deficiency in crops. Plant Soil. 339:83-95. 